\title{
Reviewer Acknowledgements for Global Journal of Health Science, Vol. 13, No. 11
}

Global Journal of Health Science wishes to acknowledge the following individuals for their assistance with peer review of manuscripts for this issue. Their help and contributions in maintaining the quality of the journal are greatly appreciated.

Global Journal of Health Science is recruiting reviewers for the journal. If you are interested in becoming a reviewer, we welcome you to join us. Please contact us for the application form at: gjhs@ccsenet.org.

\section{Reviewers for Volume 13, Number 11}

Abiodun Adeniran, University of Ilorin, Nigeria

Ama Pokuaa Fenny, University of Ghana, Ghana

António Calha, Polytechnic Institute of Portalegre, Portugal

Ayesha Johnson, University of South Florida, United States of America

Farahnaz Amini, UCSI University, Malaysia

Francisco Rodenas Rigla, University of Valencia, Spain

Gabriel Gulis, University of Southern Denmark, Denmark

Gabriele Messina, University of Siena, Italy

Gavric Zivana, University Banja Luka, Bosnia and Herzegovina

Georgann Valerie Weissman, Capella University, United States

Hülya YARDIMCI, Ankara University, Turkey

Loray Daws, British Columbia Masterson Institute, Canada

Marcel Wullschleger, University of Bern, Switzerland

Meng Zhao, Texas A\&M University at Corpus Christi, United States of America

Pedram Iranmanesh, Dentist, Independent Researcher, Iran

Pi-Ming Yeh, Missouri Western State University, United States

Robert Sloan, Kagoshima University Graduate School of Medical and Dental Sciences, Japan

Samir Othman, Hawler Medical University, Iraq

Tulyakul Phatcharapon, Boromarajonani College of Nursing, Thailand 